available to plants. These results could explain the large yield response of leeks to the application of farmyard manure which is especially marked in dry seasons.

The results of growth analyses of carrot erops grown with and without farmyard manure showed that, during the very early stages of growth, the rate of increase of dry weight was much greater on plots where farmyard manure had been applied, and that this initial difference could affect the final yield of the crops. Chemical analyses of the seedlings revealed differences in composition which were larger than might have been expected from the results of laboratory assessments of the available nutrients in the treated and untreated soils. Experiments on the uptake of nutrients by seedlings in the first five days after emergence have shown that the amount of potassium taken up during this period affects the rate of growth of the seedlings for about 35 days, irrespective of the potassium nutrient treatment given after the first 5-day period. While it appears that potassium was involved in the stimulation of growth of the seedlings on the farmyard manuretreated plots, the reason for the much greater uptake of potassium by seedlings on these plots is not known.
The effect of soil conditions on the distribution and activity of plant roots is important to the nutrient and water economy of the plant, but, unfortunately, there is little fundamental information on this subject. Some work has been done at Wellesbourne on the distribution of the root systems of various vegetable crops, and attention is now focused on devising suitable techniques for the investigation of the factors affecting root activities in defined soil systems.

In the midland, eastern and south-eastern counties of England, crop production is limited in four years out of five by insufficient rainfall. Irrigation is now widely practised in these areas and, in general, produces increased yields of most crops. However, the response to applications of irrigation water is affected by the physical condition of the soil, and on certain soils, notably silts and fine sands, yields can be decreased if irrigation water is applied in such a way that the surface of the soil is beaten down to form a 'cap'. Methods of irrigation to overcome this disadvantage are now being studied, together with the causes of the detrimental effect of the 'cap' on plant growth.
F. Haworth

\title{
SCIENCE AND EDUCATION IN COMMUNIST CHINA
}

IN a paper presented to the American Association for the Advancement of Science at its New York meeting on December 27, 1960, Dr. T. H. E. Chen, describing the position of science and scientists in Communist China, explains that to the Chinese Communist science and politics were inseparable, and every scientist had to pledge himself unreservedly and unquestioningly to the Communist party : the study of politics and ideology was as important as the study of science. Ever since 1949, increasing pressure had been exerted on China's scientists to conform politically and ideologically, and scientists were required to follow the direction of the Communist party in their scientific work. Political interference was found in many areas and the idea of objective science was rejected. As regards the present position, Dr. Chen said there was a new interest in science and technology, and technical institutes at secondary and higher levels were producing large numbers of engineers, technicians and technologists. Better facilities for scientific study had been provided since 1956-57, living conditions and salaries for scientists had been improved, and laboratory and library facilities expanded. The predominant emphasis remained on applied science and technology and also violent opposition to science for its own sake. Moreover, scientists were so hemmed in by political restrictions and burdened with political requirements that there was little room for initiative and creativity. There had, however, been a mushroom growth of new ideas in technical innovations and improvements, but despite such spectacular results, much was lacking from the point of view of a long-range and balanced programme of seientific development. There was reason to believe, however, that beneath the outward conformity a good deal of resistance to Communist pressure still existed among scientists.

In a paper on the training, growth and utilization of scientific and technical man-power in Communist China, presented at the same meeting, L. A. Orleans, of the Library of Congress, reviewed briefly the educational system in Communist China, and especially its capacity to produce scientists and technicians, and then considered the professional man-power of China, its competence and the effectiveness with which it is used. Mr. Orleans stressed the importance of using with discretion data on Communist China. Despite some revolutionary educational reforms, the framework of the educationel system is approximately that which existed under the Nationalist regime, but it is supplemented by a great variety of educational facilities which do, in fact, provide training in various subjects and skills with different degrees of complexity and intensity. Between 1949 and 1957 enrolment in primary schools increased by 40 million, in secondary schools by about 6 million and in institutions of higher education by 300,000 ; during 1958 enrolment in primary schools increased from $64 \cdot 3$ million to 86 million; in secondary schools from 7 million to 10 million; and in universities and institutes from 440,000 to 660,000 ; but inevitably the already inadequate education received by most pupils deteriorated further. The most glaring weakness in higher education is probably over-specialization : there is virtually no possibility of interchange among specialists, and in most institutions physics, for example, is no longer taught as a distinct and integrated subject. Despite the limited facilities, teachers and funds, the system provides a large number of people with an appreciation for education, and a relatively small number with the knowledge necessary to lead the drive towards industrialization and world status.

Mr. Orleans accepts the figure of 625,000 as most closely reflecting the number of persons with higher education at present living in Communist China, more than half of whom are under thirty years of age and almost 80 per cent are men. During the past few years the number of professional workers has been growing at about 10 per cent per annum, and under the Communists the greatest increase has 


\section{No. 4772 April 15, 1961}

been in engineering, followed by education and agriculture. Of 170,000 with engineering degrees, 90 per cent have received them since 1949, while of 38,000 graduates in the natural sciences, two-thirds are Communist trained. Great inefficiency appears to exist in the estimates of future man-power requirements and in placing graduates. Most of the serious scientific work is being done in the Chinese Academy of Sciences, which in 1958 had almost 6,000 research workers (almost 75 per cent being assistants, trainees or technicians), and its affiliated institutes; even here scientific research was integrated with production. In 1958 , the 650 research institutes in science and technology employed a staff of 82,100 , of whom 18,100 were research and technical workers, 14,700 in industry and communications, 1,200 in agriculture and related fields and 2,200 in medical science and public health, but it cannot be assumed that all have completed professional training. Many engineering graduates are, in fact, little more than skilled technicians and many science graduates advanced laboratory technicians. China undoubedly possesses a limited number of first-rate scientists, but, at least in the immediate future, her achievements in science, as in overall economic growth, will depend on how much help is obtained from the U.S.S.R. More and more persons will graduate from the advanced institutions now established to train scientists and technologists, but their function must be problematic while China continues the policy of adapting present knowledge to immediate needs rather than sponsoring creative research.

\section{TREATMENT OF RINGWORM BY GRISEOFULVIN}

$\mathrm{T}$ INEA CAPITIS (ringworm of the scalp) is a dermatomycosis mainly affecting groups of children of school age. Although not serious, the disease is conspicuous, and affects the morale of children, keeping them from school and from participation in normal childhood activities. The bacterial complications to which it may give rise are sometimes serious.

The disease is carried home from school or from a group of playmates, and a reservoir of infection is then established among adults. In some communities in Israel, the proportion of adults suffering from ringworm is higher among women than among men. On the other hand, in Moslem communities it appears to be the men who maintain the disease and run the risk of serious infection, because of their custom of shaving their heads, which is frequently done without due attention to hygiene. Moslem women are protected by the care they give their hair.

Ringworm is particularly widespread in communities where life is organized around the family or the tribe or where people live together in crowded conditions. Some persons contract ringworm more easily than others exposed to the same risk, and the disease is more frequent among children suffering from protein deficiency. In the (then) Belgian Congo, Vanbreusghem examined thousands of children and found that its prevalence varied between 5 and 40 per cent. It was higher in areas where serious protein deficiency was known to occur and kwashiorkor was present. The same applied to cases treated in hospital: in Bukavu, 89 per cent of the children suffering from kwashiorkor were infected with ringworm. At present it is impossible to say whether this arises from a lack of vitamin A accompanying protein deficiency, a change in the sebaceous secretion of the scalp, or some abzormality of the skin or hair related to kwashiorkor and favouring the development of fungi.

In North Africa, in some parts of Central Africa, in the Eastern Mediterranean basin, in certain parts of the United States where there is a high percentage of Negroes, and in various parts of eastern Europe, ringworm may affect 30-40 per cent of the children. The health authorities of several countries have decided to attack this problem and the World Health Organization is giving assistance to the Province of Syria, the United Arab Republic and to Tunisia. In Yugoslavia, where a systematic campaign against ringworm is under way, the Organization has assisted a demonstration project of mass griseofulvin treatment, directed by Prof. E. I. Grin. The campaign being carried out and a general survey on ringworm and its treatment are outlined in a recent issue of the $W H O$ Chronicle*.

The dermatophytic fungi (Trichophyton, Micro. sporum) live and multiply at the expense of the keratin they digest; as a result, the growth of the hair is impaired and it falls out, leaving bald patches.

The treatment used until quite recently consisted in desquamation of the parts affected so as to remove the diseased keratin, and the disinfection of the patches in order to prevent contamination of newly formed keratin. For this purpose, fungicidal ointments and pomades, and even X-ray therapy, which causes depilation, were employed. None of these methods gave reliable and permanent results. It was necessary to find a new treatment, acting internally instead of externally, that would enable keratin-producing cells to resist the fungus, and continue to resist it after they had become keratinized.

The discovery of griseofulvin provided an antibiotic satisfying these requirements. Isolated in 1939 from Penicillium griseofulvum, then from several other species of Penicillium, the antibiotic was identified chemically and used in horticulture against certain fungal plant pathogens. Its powerful fungistatic action attracted the attention of dermatologists, and, starting in 1958, investigations were carried out on its use in the treatment of certain human and animal dermatomycoses. The antibiotic gave better results than any form of treatment previously applied. It was more active when administered orally than parenterally, was not found in the serum of treated subjects, but, on the other hand, could be detected in their hair. In therapeutic doses it did not have any harmful or irreversible side effects. As a result of these outstanding properties it was decided to use it for mass treatment.

Following mass immigrations from highly endemic areas after 1948, ringworm, which had been almost unknown in Israel, again developed into a public health problem. The number of new cases reached 4,000-6,000 per annum. The good results obtained elsewhere with griseofulvin encouraged Israeli health authorities to adopt it for a mass campaign, after confirming its effectiveness and harmlessness in a

* WHO Chronicle, 15, No. 2; February 1961. 